\title{
Accounting
}

\section{Investor sentiment by relative strength index and stock return: Empirical evidence on Vietnam's stock market}

\author{
Lai Cao Mai Phuong ${ }^{a^{*}}$
}

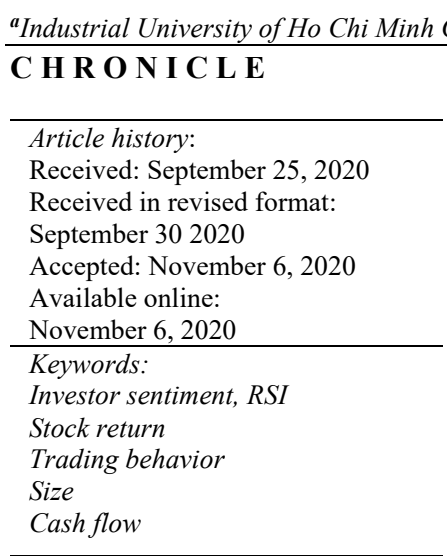
\begin{abstract}
A B S T R A C T
This article examines how investor sentiment affects stock returns on Vietnam's stock market. Investor sentiment index is measured by a relative strength index (RSI) of 57 companies listed on the Ho Chi Minh Stock Exchange from January 1, 2015 to July 31, 2020. Control variables include investors' stock trading behavior, firm size, and cash flow per share. Using Fama-MacBeth regression estimation and general least square estimation (GSL) on a daily basis, both methods find the sentiment of high investors producing higher stock returns, on the contrary, the sentiment of low investors erodes stock returns. Different from the results of Brown and Cliff (2004) [Brown, G. W., \& Cliff, M. T. (2004). Investor sentiment and the near-term stock market. Journal of empirical finance, 11(1), 1-27], the article found that the investor sentiment factor plays the most important role in explaining the return of the stock market compared to the rest of the factors.
\end{abstract}

\section{Introduction}

(C) 2021 by the authors; licensee Growing Science, Canada

The efficient market theory states that investors cannot use publicly available information such as historical stock prices or trading volume to find excess return on the stock market (Fama, 1970). However, behavioral finance studies have provided empirical evidence that investor sentiment and their behaviors can significantly affect asset returns and create excess return. Investors' behaviors related to stock valuations, such as investors' slow response to earnings announcements (Battalio \& Mendenhall, 2005), institutional investors may ignore value-oriented securities when they are no longer in favor (Lakonishok, Shleifer, Vishny, Hart \& Perry, 1992). Besides, studies also show that behaviors that affect stock returns are related to investor sentiment. Measures of investor sentiment can be based on Mutual fund flows (Frazzini \& Lamont, 2008), circadian rhythm according to the moon cycle (Phuong, 2012), positive psychology before the holidays (Phuong, 2018), avoid doing important things on bad days (Phuong, 2019), investor sentiment across the entire market (Stambaugh, Yu \& Yuan, 2012), investor sentiment is based on individual stocks (Ryu, Kim \& Yang, 2017). In addition, the results from investors' sentiment studies to the profits on the stock market are also inconsistent. While Brown and Cliff (2004) argued that the impact of investor sentiment on stock returns is negligible, on the contrary, Ryu et al. (2017) discovered that the influence of investor sentiment was very significant and cannot be ignored. Studies measuring investor sentiment in the stock market today mainly focus on major stock markets such as the US, UK (Hudson \& Green, 2015), Hong Kong (Chen, Chong \& Duan, 2010), South Korea (Ryu et al., 2017). However, the number of studies on investor sentiment based on technical analysis indicators to stock returns on emerging

* Corresponding author

E-mail address: laicaomaiphuong@iuh.edu.vn (L. C. M. Phuong) 
markets like Vietnam is quite small. Therefore, this article will explore this topic on the stock market of Vietnam. To achieve this goal, the article investigates investor sentiment based on RSI influencing the determination of profits on the stock market in Vietnam from January 1, 2015 to July 31, 2020.

\section{Research models}

To measure the sentiment index for each individual company, this article uses the relative strength index (RSI) to capture market sentiment and expectations. Eq. (1) is used to calculate the RSI. The RSI ranges from 0 to 100. The central line of the RSI is the line going through the 50 level. A stock is considered bullish when its RSI is above the central line, while it is considered a bearish signal when the RSI is below the central line. When the RSI is above 70, it indicates an overbought signal, while a stock is considered oversold when the RSI is below 30 (Murphy, 1999).

The 14-day RSI is a popular length useful by traders and used by a large number of scholars in developed stock markets (Chong $\& \mathrm{Ng}, 2008)$ to be used in this article.

$$
\begin{aligned}
R S I_{i, t}= & \frac{R S_{i, t}}{1+R S_{i, t}} \times 100, \\
R S_{i, t}= & \frac{\sum_{k=0}^{13} \max \left(0, P_{i, t-k}-P_{i, t-1-k}\right)}{\sum_{k=0}^{13} \max \left(0, P_{i, t-k-1}-P_{i, t-k}\right)},
\end{aligned}
$$

where: $P_{i, t}$ is the closing price of stock $i$ on date $t$. Set up the index of investors' trading behavior on the Vietnam stock market (BSd). Firstly, it is necessary to calculate the raw buy and sell trade imbalance (BSV). BSV is calculated by the ratio of the difference between the actual buying and selling volumes compared to the total volume of buy and sell. BSV is calculated daily for each share based on Eq. (2).

$$
B S V_{i t}=\frac{\left(B V_{i t}-S V_{i t}\right)}{\left(B V_{i t}+S V_{i t}\right)} .
$$

Here: $B V_{i, t}$ is the volume of total buy transactions for stock $i$ on day $t$ by local investors. $B V_{i, t}$ is the volume of total sell transactions for stock $i$ on day $t$ by local investors.

Stock $i$ is overbought by local investors if Eq. (2) is greater than zero, and stock $i$ is overbought by local investors if Eq. (2) is less than zero.

Next, the buy and sell trade imbalance index (BSd) is the residual in the regression Eq. (3):

$$
B S V_{i, t}=\beta_{0}+\beta_{1}\left(R_{t}-R_{t}\right)+u_{i, t}
$$

In which, $R m_{t}$ and $R f_{t}$ are the return of the market and the risk-free rate at time t respectively.

To test the net effect when combining both sentiment and trading behavior of investors to excess return on Vietnam's stock market, the article regression follows the equation:

$$
R_{i, t}=\beta_{0}+\beta_{1} R S I_{i, t}+\beta_{2} B S d_{i, t}+\beta_{3} S i z e_{i, t-1}+\beta_{4} C F_{i, t-1}+e_{i, t}
$$

Here: $R_{i, t}$ is the excess return calculated by the difference between the return of stock $i$ and the interest rate of the risk-free asset. Return is calculated in logarithm of the share price of day $t$ versus date $t-1$, using the 1-year government bond rate as the riskfree rate. To control financial factors according to the characteristics of each company, the article uses financial data of the preceding period, including variables: Size and CF. Size is the size of the company, calculated by the daily closing price multiplied by the number of shares outstanding. CF is cash flow per share, $e_{i, t}$ is the remaining return of each share $i$ at time $t$. Five estimation models to test the impact of investor sentiment on stock returns on Vietnam's stock market are set up, these models are based on Eq. (4). The first model does not include the variable measuring investor sentiment, its regression based on Eq. (4) but has a coefficient $\beta_{1}=0$. The second pattern is the general emotional effect of investors on returning stocks in all 
trading stages. The remaining three models test the sentiment effect of investors according to the level of their sentiment on stock returns. In the case of low investor sentiment and pessimism, the RSI falls below 30, which is manifested in model 3. Investor sentiment when the stock price shows signs of increase, RSI exceeds the level of 50, which is shown in the model 4. Finally, pattern 5 indicates overly excited investor sentiment when the RSI is above 70 .

Based on the steps in building the research model, the article maps out the implementation process as follows:

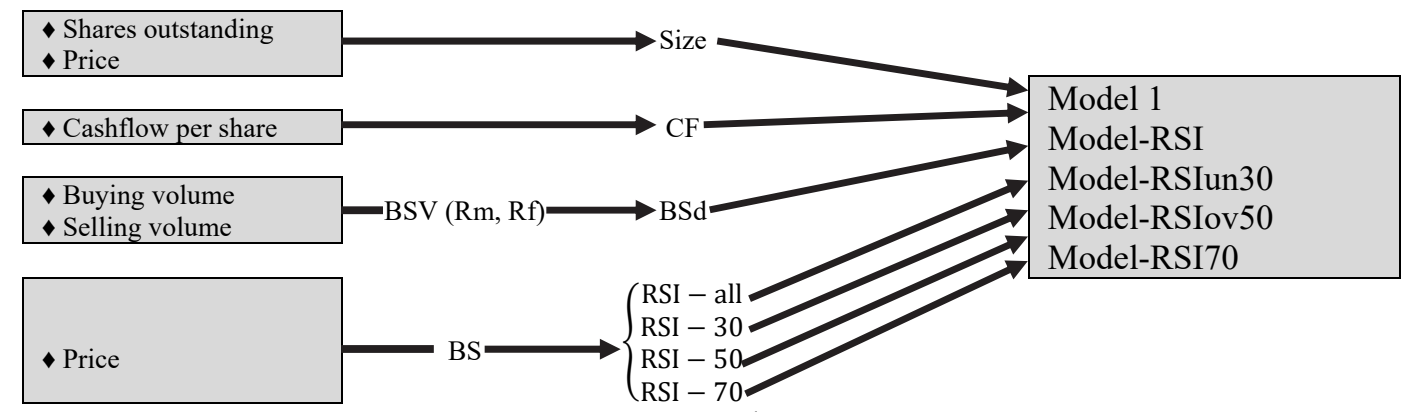

Fig. 1. Research process

Source: The author builds on the previous studies

\section{Data}

The article uses stock trading data and financial data of companies listed on the Ho Chi Minh City Stock Exchange for more than 6 years. In which, data on securities transactions under VN100 is collected daily from January 1, 2015 to July 31, 2020, quarterly financial data of each company is collected from quarter 1, 2015 to quarter 2, 2020. From the list of 100 companies in the VN100 basket published by HSX in July 2020, the article is after excluding companies with insufficient financial data or those companies that had a suspension of transactions between 2015 and July 2020, the research data remained 57 firms.

\section{Estimation method}

Two estimation methods were used in this study. First, the paper uses the Fama-MacBeth estimation technique to regress daily data. The Fama-MacBeth method is designed to deal with time effects, so the standard errors of the parameters estimated by this method will not be biased and are relatively efficient compared to OLS estimates. In the event that the estimated errors according to Fama-MacBeth are biased and its magnitude will increase as the firm effect increases, correct it by using the Newey-West standard error. (Newey-West, 1987). The Newey-West standard errors adjusted for panel data are skewed but to a very small extent. Second, the GLS estimation method was performed based on the same data set of 57 listed companies. If the results from these two methods are nearly the same, it will prove the stability of the research model.

\section{Research results}

\subsection{Fama-MacBeth estimation results}

Table 1 presents the estimated results for the 5 research models.

\section{Table 1}

Fama-MacBeth estimation results from the models

\begin{tabular}{|c|c|c|c|c|c|}
\hline Variable & (1) & (2) & (3) & (4) & $(5)$ \\
\hline $\mathrm{BSd}$ & $1.0843 * * *$ & $0.9329 * * *$ & $1.0982 * * *$ & $1.0201 * * *$ & $0.9766^{* * *}$ \\
\hline Size & $-0.0054 *$ & $-0.0226 * * *$ & -0.0100 & $-0.0158 * *$ & -0.0071 \\
\hline $\mathrm{CF}$ & $0.0000 * * *$ & 0.0000 & $0.0000 * * *$ & $0.0000 * * *$ & $0.0000 * * *$ \\
\hline RSI & & $0.0603 * * *$ & & & \\
\hline RSIun30 & & & $-1.4277 * * *$ & & \\
\hline RSIov50 & & & & $1.0500 * * *$ & \\
\hline RSIov70 & & & & & $1.3293 * * *$ \\
\hline cons & 0.1498 & $-2.2813 * * *$ & $0.3978 * *$ & -0.0078 & 0.1037 \\
\hline $\bar{N}$ & 75400 & 75400 & 75400 & 75400 & 75400 \\
\hline $\mathrm{r} 2$ & 0.0998 & 0.2226 & 0.1474 & 0.1691 & 0.1502 \\
\hline adjr2 & 0.0663 & 0.1785 & 0.0990 & 0.1218 & 0.1019 \\
\hline
\end{tabular}


Model 1: In this model, there are no variables measuring investor sentiment. All three regression coefficients in this model are statistically significant, indicating that investor buy and sell trade imbalances (BSd), firm size (size) and cash flow per share (CF) are factors that have significant impact on the stock's daily outstanding return. The two factors that represent the characteristics of a company, the variable Size has a negative impact on the daily return of the stock. It shows that the larger companies with large volume of shares circulating in the market will limit the ability of this stock to increase in price. The higher the cash flow per share will create the motivation for the share price to increase.

Of the four models with additional variables measuring investor sentiment, only the fourth model - using an RSI greater than 50 - has regression results on the effects of factors on the excess return is the same as in model 1. The different result of the fourth model compared to model 1 is that it has added the impact of investor sentiment in an optimistic mood that will have a positive impact on the return of the stock. The common point of the third model (adding RSI variable less than 30- RSIun30) and the fifth model (adding the variable RSI greater than 70-RSIov70) is the regression coefficient of the variable size that has lost statistical significance. This result shows that when the mood is in a depressed state (RSIun30) or when they are in a state of euphoria (RSIov70), the firm size factor will be obscured and no longer has a significant impact on stock returns. The regression coefficient of the RSIun30 variable is negative and the RSIov70 variable is greater than zero indicating that when investor sentiment is depressed / excited, it will have a negative / positive effect on daily returns of stocks. When measuring investors' sentiment but do not clearly separate each stage of their sentiment as depression, positive and euphoria, the regression results are presented in model 2. Compared with model 1, the regression coefficient of CF variable is not statistically significant. This shows that the mixed sentiment of investors in the periods will overshadow the impact of the cash flow factor per share on the daily returns of these stocks. The coefficient of RSI variable is greater than zero, showing that investor sentiment in this period was positive and it had a positive impact on the price of stocks.

The research results show that investor sentiment is an important factor affecting profits on the stock market of Vietnam. The results of this study support the results of Ryu et al. (2017). When positive investor sentiment is associated with higher stock returns. Conversely, when investor sentiment is low, it causes a drop in stock returns. This article also proves that Vietnam's stock market is inefficient in a weak form.

The regression results from the five models show that the regression coefficients of BSd are all positive, showing that the domestic investors' trade imbalance is positive with the returns of these stocks.

When comparing the regression coefficient of the variable BSd and the variables measuring investor sentiment in the models (2), (3), (4), (5), the role of the sentiment factor of the investors Stock investment is more obvious when the stock has buy (sell) signals or when the stock is in overbought and oversold condition.

The regression coefficient of SIZE is less than zero, indicating that companies with high capitalization have a negative impact on stock returns when stocks show upside signals. It is noteworthy that the importance of a stock's size variable loses when its price falls into overbought and oversold zones. This is shown when the regression coefficient of SIZE is not statistically significant in model (3) and (5). The regression coefficient CF- cash flow per share is positive, indicating that this variable positively affects stock returns.

In the estimation models, only model (1) does not measure investor sentiment in the stock market. Based on the R2 and adjR2 statistics of the regression models, it shows that four models using the variable to measure investor sentiment in the stock market explain significantly better than the model (1). This result supports the view that the influence of investor sentiment on stock returns in Vietnam stock market is very significant and cannot be ignored. It supports the point of Ryu et al. (2017) and do not support the results of Brown \& Cliff (2004).

\subsection{Robustness checks}

\section{Generalized least squares estimation results}

In order to check the robustness of the estimation results, the paper uses the same regression data in a different method. When using different estimation methods, then comparing the results between these methods are similar, the regression results ensure robustness checks. In this section, the GLS estimate is used. After correcting the model defects in variance and series correlation, the regression results are presented in Table 2. 
Table 2

Regression results according to GLS method

\begin{tabular}{|c|c|c|c|c|c|}
\hline Variable & (1) & $(2)$ & (3) & (4) & $(5)$ \\
\hline $\mathrm{BSd}$ & $1.5931 * * *$ & $1.4366 * * *$ & $1.5678 * * *$ & $1.5123 * * *$ & $1.4577 * * *$ \\
\hline Size & -0.0046 & $-0.0259 * * *$ & $-0.0116^{* *}$ & $-0.0175 * * *$ & -0.0089 \\
\hline $\mathrm{CF}$ & $0.0000 * * *$ & -0.0000 & $0.0000 * * *$ & 0.0000 & 0.0000 \\
\hline RSI & & $0.0595 * * *$ & & & \\
\hline RSIun30 & & & $-1.9158 * * *$ & & \\
\hline RSIov50 & & & & $1.0830 * * *$ & \\
\hline RSIov70 & & & & & $1.6453 * * *$ \\
\hline cons & 0.1818 & $-2.1366 * * *$ & $0.5117 * * *$ & 0.0473 & 0.2046 \\
\hline $\bar{N}$ & 75400 & 75400 & 75400 & 75400 & 75400 \\
\hline F test & 34.48 & 35.36 & 34.46 & 35.24 & 33.12 \\
\hline Wald test & 1201.25 & 1375.05 & 1249.91 & 1287.07 & 1197.21 \\
\hline Hausman test & 1954.45 & 1852.60 & 1952.19 & 1974.50 & 1858.44 \\
\hline Wooldridge test & 1292.245 & 753.261 & 1278.019 & 1364.461 & 1294.122 \\
\hline Prob $>$ chi 2 & 0.0000 & 0.0000 & 0.0000 & 0.0000 & 0.0000 \\
\hline
\end{tabular}

Source: Author's calculations

Notes: $* p<0.1 ; * * p<0.05 ; * * * p<0.01$

Tests with P-value $<0.05$ showed that the generalized least squares method (GLS) is more suitable than the POLS estimates, the fixed effects regression model (FEM), the model random effects (REM). Restricted F test, and the Hausman test in the models show that FEM is better than POLS and REM. However, the Wald test and the Wooldridge test revealed the problem of heteroskedasticity and autocorrelation of standard errors. To overcome these problems, the paper uses the general least squares method (GLS) to obtain estimates of efficiency (Gujarati, 2009).

In general, the variables with the statistically significant impact on stock returns presented in Table 1 are quite similar to the results in Table 2. The investor imbalance factor in buy and sell (BSd) transactions maintains an impact on stock returns throughout the five models studied by both Fama-MacBeth and GLS estimation methods. It turns out that the supply-demand factor of stocks in the market has a persistent effect on the returns of these stocks. Firm size (size) and cash flow per share (CF) are statistically significant in several regression models. These results suggest that the effect of a firm's idiosyncrasies on stock returns is yes but these factors may be overwhelmed by factors other than it.

Similar to the regression results in Table 1, the results from Table 2 confirm that the role of investor sentiment in explaining stock returns on Vietnam's stock market is stronger than the factors remaining in research models. This result is confirmed when the regression coefficients of the variables measuring investor sentiment in $8 / 8$ models have statistical significance of $1 \%$ and sign consistency in both estimation methods. Comparing the regression results between Table 1 and Table 2 shows that the regression results are reliable and robustness checks guarantee.

\section{Conclusions}

This has been one of the first studies to measure investor sentiment in Vietnam's stock market based on RSI. The paper uses two estimation methods according to Fama-MacBeth and GLS to ensure the stability of the research models and the reliability of the regression results. The results from both methods indicate that investor sentiment exerts more explanatory power in determining stock returns compared to the trading behavior of local investors, financial factors and individual characteristics of each stock. The role of stock investor sentiment to stock returns is to outperform the rest of the research model when the stock is signaling to buy (sell) or it is in the overbought or oversold area.

\section{References}

Battalio, R. H., \& Mendenhall, R. R. (2005). Earnings expectations, investor trade size, and anomalous returns around earnings announcements. Journal of Financial Economics, 77(2), 289-319.

Brown, G. W., \& Cliff, M. T. (2004). Investor sentiment and the near-term stock market. Journal of empirical finance, 11(1), $1-27$.

Chen, H., Chong, T. T. L., \& Duan, X. (2010). A principal component approach to measuring investor sentiment. Quantitative Finance, 10, 339-347.

Chong, T. T. L., \& Ng, W. K. (2008). Technical analysis and the London stock exchange: testing the MACD and RSI rules using the FT30. Applied Economics Letters, 15(14), 1111-1114.

Fama, E. F. (1970). Efficient capital markets: A review of theory and empirical work. The journal of Finance, 25(2), 383-417. DOI: $10.2307 / 2325486$. 
Frazzini, A., \& Lamont, O. A. (2008). Dumb money: Mutual fund flows and the cross-section of stock returns. Journal of financial economics, 88(2), 299-322.

Gujarati, D. N. (2009). Basic econometrics. Tata McGraw-Hill Education. Chapter 16.

Hudson, Y., \& Green, C. J. (2015). Is investor sentiment contagious? International sentiment and UK equity returns. Journal of Behavioral and Experimental Finance, 5, 46-59.

Murphy, J. J. (1999). Technical analysis of the financial markets: A comprehensive guide to trading methods and applications. Penguin.

Newey, W. K., and K. D. West. (1987). A simple, positive semi-definite, heteroskedasticity and autocorrelation consistent covariance matrix. Econometrica55: 703-708.

Lakonishok, J., Shleifer, A., Vishny, R. W., Hart, O., \& Perry, G. L. (1992). The structure and performance of the money management industry. Brookings Papers on Economic Activity. Microeconomics, 1992, 339-391. DOI: 10.2307/2534766.

Phương, L. C. M. (2012). Nghiên cứu ảnh hưởng của chu kỳ mặt trăng đến lợi suất tại thị trường chứng khoán Việt Nam. Tạp chí Phát triển và hội nhập, 2(2012), 75-78.

Phuong, L. C. M. (2017). The correlation of geomagnetic field to VNIndex return. Banking Technology Review, 1(1), 65-81.

Phuong, L. C. M. (2019). Tỷ suất sinh lợi của VN-Index và HNX-Index vào những ngày đầu tháng âm lịch. Tạp chí Tài chính, $1(708), 92-95$.

Phuong, L. C. M. (2020). Investor sentiment by psychological line index and stock return. Accounting, 6(7), $1259-1264$.

Phuong, L. C. M. (2018). Hiệu ứng trước kỳ nghỉ lễ tác động đến tỷ suất sinh lợi VN-Index và HNX-Index. Tạp chí Tài chính, $1(686), 76-79$.

Ryu, D., Kim, H., \& Yang, H. (2017). Investor sentiment, trading behavior and stock returns. Applied Economics Letters, 24(12), 826-830.

Stambaugh, R. F., Yu, J., \& Yuan, Y. (2012). The short of it: Investor sentiment and anomalies. Journal of Financial Economics, 104(2), 288-302.

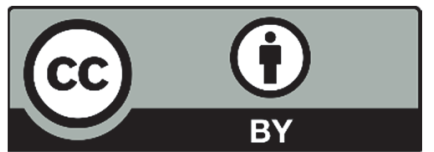

(C) 2021 by the authors; licensee Growing Science, Canada. This is an open access article distributed under the terms and conditions of the Creative Commons Attribution (CC-BY) license (http://creativecommons.org/licenses/by/4.0/). 